\title{
ISTORIJSKI PREGLED: ZNAČAJ KOMBINACIJE DHBP I FENTANILA TOKOM BALANSIRANE ANESTEZIJE NA PROMENE TOKOM LAPAROSKOPSKE HOLECI- STEKTOMIJE (Uticaj različitih tehnika anestezije na kardiovaskularni sistem)
}

\author{
Marko Đurić ${ }^{1}$, Miljan Milanović ${ }^{2}$, Vesna Stevanović ${ }^{3}$, Irina Nenadić 1 , Marina Boboš ${ }^{1}$, Predrag Stevanovićl,4 \\ ${ }^{1}$ Klinika za anesteziologiju i intenzivno lečenje, Kliničko-bolnički centar „Dr Dragiša Mišović”, Beograd, Srbija \\ ${ }^{2}$ Klinika za hirurgiju, Kliničko-bolnički centar „Dr Dragiša Mišović”, Beograd, Srbija \\ ${ }^{3}$ Institut za zdravstvenu zaštitu majke i deteta Srbije „Dr Vukan Čupić”, Beograd, Srbija \\ ${ }^{4}$ Medicinski fakultet Univerziteta u Beogradu, Beograd, Srbija
}

\section{Sažetak}

Uvod: Anestezija tokom operacije neminovno dovodi do niza hemodinamskih promena kod bolesnika. Ovaj efekat je još izraženiji tokom laparoskopskih procedura. Klinička studija prikazana u ovom radu sprovedena je pre gotovo dve decenije, a njen cilj bio je da se ustanovi koja od ispitivanih anestezioloških tehnika tokom laparoskopske holecistektomije obezbeduje najbolju kombinaciju potrebne dubine anestezije, uz najmanje negativno dejstvo na hemodinamiku bolesnika. Ova studija, pre svega, ima istorijski značaj, a njeni rezultati nam i danas mogu biti od koristi pri kliničkom prosudivanju i odlučivanju u određenim situacijama u kojima se možemo naći u svakodnevnom radu. Metod: Prospektivnom longitudinalnom studijom, koja je izvedena tokom 1999. i 2000. godine, a u koju je uključeno 90 pacijenata, ispitivali smo hemodinamske uticaje tri razlicite tehnike anestezije tokom laparoskopske holecistektomije kod hroničnog holecistitisa:opšte balansirane anestezije, totalne intravenske anestezije i uvoda i održavanja anestezije inhalacionim anestetikom. Hemodinamske funkcije pacijenta smo pratili i procenjivali kroz sledeće parametre: sistolni i dijastolni krvni pritisak, srčanu frekvencu, ukupni periferni otpor, minutni volumen i srčani indeks. Odredeno je sedam perioperativnih momenata za merenje hemodinamskih parametara, dobijene vrednosti su poredene izmedu grupa. Rezultat: $U$ ovoj studiji su sve tri primenjene tehnike anestezije pokazale statistički visoko značajnu razliku u vrednostima sistolnog $i$ dijastolnog pritiska, a promene su najviše bile izražene pri balansiranoj anesteziji. S obzirom na to da hemodinamske varijable u ovom istraživanju nisu merene invazivno, zaključci bazirani na prikupljenim podacima mogu samo da upute na trend promena ostalih hemodinamskih parametara, koji se mere invanzivno (udarni volumen, minutni volumen, srčani indeks, itd.). Zaključak: Sa hemodinamske tačke gledišta, rezultati naše studije idu u korist anestetičkih tehnika totalne intravenske anestezije i uvoda i održavanja anestezije inhalacionim anestetikom. Ovim tehnikama je

\section{Abstract}

Introduction: It is unavoidable that anesthesia during surgery leads to a number of hemodynamic changes in patients. This effect is even more pronounced during laparoscopic procedures. The clinical study presented in this paper was conducted nearly two decades ago, and its goal was to determine which of the tested techniques of anesthesia during laparoscopic cholecystectomy provide the best combination of the required depth of anesthesia with the least negative effect on the hemodynamics of the patients. This study is primarily of historical significance, but its results can still be useful today in clinical judgment and decision-making in certain situations in which we can find ourselves in everyday work. Method: By prospective longitudinal study during 1999. and 2000, which included 90 patients, we performed three different anaesthetic techniques, during laparoscopic cholecystectomy in chronic cholecystitis: general balanced anaesthesia, total intravenous anaesthesia and volatile induction and maintenance anaesthesia. We assessed patient's hemodynamic functions during these operations through following parameters: systolic and diastolic blood pressure, heart rate, total peripheral resistance, cardiac output and cardiac index. Seven predefined perioperative moments had been chosen to measure the hemodynamic parameters, and the values are compared between the groups. Result: In this study, all three applied anesthesia techniques showed a statistically significant difference in the values of systolic and diastolic pressure, and the changes were most pronounced in balanced anesthesia. Since the haemodynamic variables in this study were not measured invasively, the conclusions based on the collected data can only indicate the trend of changes in other haemodynamic parameters, which are invasively measured (impact volume, minute volume, heart index, etc.). Conclusion: From the hemodynamic point of view, the results of our study are in favour of the total intravenous anesthesia and volatile introduction and maintance of anesthesia. Safe and simple control of the 
omogućena sigurna i jednostavna kontrola dubine anestezije, kao i njeno efikasno prilagodavanje intenzitetu hirurških stimulusa u svakom momentu operacije.

Ključne reči: laparoskopska holecistektomija; anestezija; hemodinamika

\section{Uvod}

$\mathrm{L}$ aparoskopska hirurgija se već dugi niz godina uobičajeno primenjuje kako u svetu tako i kod nas, posebno u opštoj i kolorektalnoj hirurgiji, u ginekologiji, pa i u nekim drugim hirurškim granama medicine. Jedna od uobičajenih procedura je i laparoskopska holecistektomija (LC), najčešće zbog holelitijaze i hroničnog holecistitisa. Bolesnici koji se podvrgavaju LC često imaju različite komobirditete. Karakteristike izvođenja samog operativnog zahvata, kao što su pozicija pacijenta na operativnom stolu, zajedno sa pozitivnim intraabdominalnim pritiskom, kreiranim insuflacijom ugljen-dioksida $\left(\mathrm{CO}_{2}\right)$ u trbušnu duplju, determinišu specifične perioperativne patofiziološke događaje kod bolesnika ${ }^{1}$. Sveuku pan morbiditet i mortalitet kod LC podjednako zavise kako od hirurških tako i od anestezioloških procedura tokom čitavog perioperativnog perioda. Opšte je poznato da na funkciju kardiovaskularnog sistema veliki uticaj imaju različite anesteziološke procedure i anestetici, koji izazivaju različite fiziološke promene $^{2}$. Veoma je važno izabrati onu tehniku anestezije koja ima najmanji negativan uticaj na kardiovaskularni sistem bolesnika, a samim tim i na morbiditet i mortalitet kod $\mathrm{LC}^{3}$.

Klinička studija prikazana u ovom radu je sprovedena pre gotovo dve decenije, a njen cilj je bio da se ustanovi koja od ispitivanih anestezioloških tehnika tokom laparoskopske holecistektomije obezbeđuje najbolju kombinaciju potrebne dubine anestezije, uz najmanje negativno dejstvo na hemodinamiku bolesnika. Ova studija, pre svega, ima istorijski značaj, ali nam njeni rezultati i danas mogu biti od koristi pri kliničkom prosuđivanju i odlučivanju u određenim situacijama u kojima se možemo naći u svakodnevnom radu.

\section{Metod}

Prospektivnom longitudinalnom studijom, sprovedenom 1999. i 2000. godine, sa simultanim depth of anaesthesia and its effective adjustment to the intensity of surgical stimuli at every moment of operation are made possibly by these techniques.

Key words: laparoscopic cholecystectomy; anesthesia; hemodynamics

kontrolnim grupama i ponovljenim merenjima, ispitivali smo hemodinamske uticaje različitih tehnika anestezije kod laparoskopske holecistektomije zbog hroničnog holecistitisa. Izveli smo tri različite tehnike anestezije: opštu balansiranu anesteziju (General Balanced Anaesthesia - GBA), totalnu intravensku anesteziju (Total Intravenous Anaesthesia - TIVA) i uvod i održavanje anestezije inhalacionim anestetikom (Volatile Induction and $M a-$ intenance of Anaesthesia -VIMA). Hemodinamske funkcije pacijenta, tokom ovih procedura, pratili smo i procenjivali kroz sledeće parametre: sistolni krvni pritisak (systolic blood pressure - SBP), dijastolni krvni pritisak (diastolic blood pressure DBP), srčanu frekvencu (heart rate - HR), ukupni periferni otpor (total peripheral resistance - TPR), minutni volumen (cardiac output - CO) i srčani indeks (cardiac index - CI).

U studiju je uključeno 90 bolesnika, zakazanih za elektivnu laparoskopsku holecistektomiju zbog hroničnog holecistitisa, a studija je prethodno odobrena od strane Etičkog komiteta Kliničko-bolničkog centra „Dr Dragiša Mišović”, gde je i sprovedena. Svi bolesnici su dali svoj pristanak za učestvovanje u kliničkom istraživanju. Kriterijumi za uključivanje bolesnika u studiju su bili: godine života (stariji od 18, a mlađi od 65 godina) i skor I prema ASA klasifikaciji (American Society of Anesthesiologists).

Kriterijumi za isključenje pacijenata iz studije su bili: neispunjavanje pomenutih kriterijuma, pacijenti sa poznatim ili suspektnim poremećajima funkcije kardiovaskularnog i respiratornog sistema, zatim oni sa poremećajima bubrežnih, metaboličkih ili neuromuskularnih funkcija, pacijenti sa poznatom ili suspektnom alergijom na bilo koji od lekova koji se koriste u toku lečenja, upotreba lekova koji mogu da stupe u interakciju sa lekovima koji se koriste u toku lečenja (i na taj način utiču na rezultate u studiji) i nepristajanje na učestvovanje u studiji.

Svi pacijenti uključeni u studiju su prostom randomizacijom podeljeni u tri grupe, prema rastućem broju istorije bolesti, i to tako što je sva- 
ki prvi bolesnik (ukoliko ispunjava kriterijume za ulazak u studiju) bio podvrgnut opštoj balansiranoj anesteziji (prva grupa - GBA), svaki drugi totalnoj intravenskoj anesteziji (druga grupa - TIVA), a svaki treći inhalacionom uvodu i održavanju anestezije (treća grupa - VIMA). Svaka grupa je sadržala po 30 pacijenata.

Svi pacijenti su premedicirani intramuskularnom upotrebom atropin-sulfata i midazolama, 30 minuta pre uvoda, $\mathrm{tj}$. indukcije $\mathrm{u}$ anesteziju.

Grupa I: Anestezija je indukovana intravenskom upotrebom natrijum tiopentala $5 \mathrm{mg} / \mathrm{kg}$, dopunjenom talamonalom, koji je tada još uvek bio u širokoj upotrebi, i to u dozi od $0,015 \mathrm{ml} / \mathrm{kg}$, i fentanilom 1,5 $\mu \mathrm{g} / \mathrm{kg}$. Endotrahealna intubacija je izvedena 2 minuta nakon administracije rokuronijum bromida $0,6 \mathrm{mg} / \mathrm{kg}$. Anestezija je održavana sa $65 \%$ azot-oksidula u kiseoniku, a bol je tokom operacije kupiran fentanilom, dok je mišićna relaksacija održavana rokuronijum bromidom.

Grupa II: Anestezija je indukovana kontinuiranom intravenskom administracijom propofola, brzinom $8 \mathrm{mg} / \mathrm{kg} / \mathrm{h}$, dopunjenom midazolamom $0,05 \mathrm{mg} /$ $\mathrm{kg}$ i remifentanilom $0,5 \mu \mathrm{g} / \mathrm{kg}$. Endotrahealna intubacija je izvedena 2 minuta nakon administracije rokuronijum bromida u dozi od $0,6 \mathrm{mg} / \mathrm{kg}$. Nakon uvoda $\mathrm{u}$ anesteziju, nastavljena je kontinuirana intravenska infuzija propofola, sada brzinom $6 \mathrm{mg} /$ $\mathrm{kg} / \mathrm{h}$ i remifentanila $0,55 \mu \mathrm{g} / \mathrm{kg} / \mathrm{min}$. Anestezija je održavana sa $35 \%$ kiseonika u vazduhu.

Grupa III: Anestezija je indukovana upotrebom sevoflurana 8 vol\% (4 MAC). Endotrahealna intubacija je izvedena 2 minuta nakon administracije rokuronijum bromida $0,6 \mathrm{mg} / \mathrm{kg}$. Za održavanje je korišćen sevofluran (1,5-2,5 MAC) u kombinaciji sa $65 \%$ azot-oksidula u kiseoniku.

Svi pacijenti su mehanički ventilirani $(\bmod$ ventilacije intermitentnim pozitivnim pritiskom -IPPV), a pritisak ugljen-dioksida u izdahnutoj smeši gasova na kraju ekspirijuma (end-tidal carbon dioxide, $\mathrm{ETCO}_{2}$ ) održavan je između 35 i 40 $\mathrm{mmHg}$, podešavanjem parametara ventilacije $\mathrm{u}$ toku procedure. Takođe, svi su dobili intravensku infuziju izotoničkih kristaloidnih rastvora $5 \mathrm{ml} /$ $\mathrm{kg} / \mathrm{h}$. Položaj pacijenata je promenjen iz položaja supinacije u anti-Trendelenburg položaj za $20^{\circ}$, nakon indukcije anestezije. Pristupom na umbilikusu, Veress iglom je kreiran pneumoperitoneum.
Povezivanjem sa $\mathrm{CO}_{2}$ insuflatorom, dostignut je, a potom i održavan, intraabdominalni pritisak od 14 $\mathrm{mmHg}$.

Za praćenje kardiovaskularnih parametara je korišćen monitor „Dash 3000”. Svi podaci sa monitora i mašine za anesteziju („Dräger Julian”) snimljeni su upotrebom RECAll AIMS (Informativni menadžment sistem za anesteziju - Anesthesia Information Management System), kompjuterizovanog sistema za praćenje anesteziološkog procesa, koji koristi unapred programirane STARR hemodinamske formule za računanje svih neophodnih varijabli iz neinvazivno dobijenih podataka.

Izabrano je sedam unapred određenih perioperativnih momenata za merenje hemodinamskih parametara: pre uvoda $\mathrm{u}$ anesteziju $\left(\mathrm{t}_{1}\right)$, odmah nakon endotrahealne intubacije $\left(t_{2}\right), 5$ minuta nakon postavljanja pacijenta $\mathrm{u}$ anti-Trendelenburg položaj za $20^{\circ}$ i levi semilateralni položaj $\left(t_{3}\right), 5$ minuta nakon započinjanja intraperitonealne insuflacije CO2 $\left(t_{4}\right), 15$ minuta nakon insuflacije CO2 (tj. tokom hirurškog rada na žučnoj kesi $-t_{5}$ ), $u$ toku plasiranja šavova na kožu trbuha $\left(t_{6}\right)$ i 5 minuta nakon buđenja pacijenta $\left(t_{7}\right)$. Ovi momenti su izabrani za komparaciju na osnovu dobro poznatih događaja u toku operacije koji utiču na promenu kardiovaskularnih parametara.

Svi dobijeni podaci su obrađeni u programu za statističku obradu i analizu podataka SPSS/PC + v.5.0 (Statistic Package for Social Sciences for PC). Primenjene su sledeće metode deskriptivne statistike: mere centralne tendencije (aritmetička sredina $-\mathrm{x}$, $\mathrm{u}$ tekstu srednje vrednosti), mere varijabilnosti (opseg varijacije - max-min i standardna devijacija - SD) i relativni brojevi. Primenjene su sledeće metode analitičke statistike: metode za identifikaciju empirijskih raspodela i metode za procenu značaja razlike: $\chi 2$ test, unifaktorijalna analiza varijanse (jednosmerna ANOVA) i multifaktorijalna analiza varijanse (MANOVA). Da bi se ustanovio značaj promena kardiovaskularnih parametara unutar grupa u posmatranom periodu, kao i da bi se identifikovala značajnost ovih promena između grupa, korišćena je multifaktorijalna analiza varijanse (MANOVA).

\section{Rezultati}

Prva serija statističke analize je proveravala osnovne podatke: zastupljenost polova, starost, 
telesnu masu (body weight - BW), telesnu visinu (body height - $\mathrm{BH}$ ), indeks telesne mase (body mass index - BMI) i telesnu površinu (body surface area-BSA). (tabele 1 i 2)

Tabela 1: Zastupljenost polova po grupama
GBA-TIVA, GBA-VIMA i TIVA-VIMA (prikazano kao $1 \rightarrow 2,2 \rightarrow 3,3 \rightarrow 4,4 \rightarrow 5,5 \rightarrow 6$, $6 \rightarrow 7)$.

\begin{tabular}{|l|c|c|c|c|c|c|}
\hline \multirow{2}{*}{ Pol } & \multicolumn{2}{|c|}{ GBA } & \multicolumn{2}{c|}{ TIVA } & \multicolumn{2}{c|}{ VIMA } \\
\cline { 2 - 7 } & Broj & \% & broj & \% & broj & \% \\
\hline Muškarci & 13 & 43,3 & 11 & 36,7 & 12 & 40,0 \\
\hline Žene & 17 & 56,7 & 19 & 63,3 & 18 & 60,0 \\
\hline Ukupno & 30 & 100,0 & 30 & 100,0 & 30 & 100,0 \\
\hline
\end{tabular}

$\chi^{2}=0,278 ; \mathrm{df}=1 ; \mathrm{p}>0,05$

Legenda: GBA - opšta balansirana anestezija, TIVA - totalna intravenska anestezija, VIMA - volatilna indukcija i održavanje anestezije

Tabela 2: Deskriptivni statistički parametri i značaj razlika u srednjim vrednostima osnovnih karakteristika pacijenata po grupama

\begin{tabular}{|c|c|c|c|c|c|c|c|c|}
\hline Karakteristike & Grupa & $\mathrm{x}$ & SD & Min & $\max$ & $\mathrm{F}$ & df & $\mathrm{p}$ \\
\hline \multirow{3}{*}{ Godine } & GBA & 48.50 & 7.57 & 36.00 & 64.00 & \multirow{3}{*}{0.428} & \multirow{3}{*}{$2 ; 87$} & \multirow{3}{*}{ ns } \\
\hline & TIVA & 48.27 & 7.89 & 36.00 & 65.00 & & & \\
\hline & VIMA & 46.73 & 8.60 & 34.00 & 64.00 & & & \\
\hline \multirow{3}{*}{ Telesna težina } & GBA & 83.03 & 11.00 & 65.00 & 108.00 & \multirow{3}{*}{1.554} & \multirow{3}{*}{$2 ; 87$} & \multirow{3}{*}{$\mathrm{ns}$} \\
\hline & TIVA & 80.53 & 9.17 & 63.00 & 96.00 & & & \\
\hline & VIMA & 78.23 & 11.34 & 56.00 & 105.00 & & & \\
\hline \multirow{3}{*}{ Telesna visina } & GBA & 1.70 & 0.11 & 1.55 & 1.92 & \multirow{3}{*}{0.424} & \multirow{3}{*}{$2 ; 87$} & \multirow{3}{*}{ ns } \\
\hline & TIVA & 1.69 & 0.10 & 1.54 & 1.84 & & & \\
\hline & VIMA & 1.68 & 0.12 & 1.52 & 1.98 & & & \\
\hline \multirow{3}{*}{ BMI } & GBA & 28.61 & 3.83 & 20.37 & 34.16 & \multirow{3}{*}{0.429} & \multirow{3}{*}{$2 ; 87$} & \multirow{3}{*}{ ns } \\
\hline & TIVA & 28.39 & 3.26 & 24.21 & 37.25 & & & \\
\hline & VIMA & 27.76 & 3.93 & 19.66 & 36.79 & & & \\
\hline \multirow{3}{*}{ BSA } & GBA & 1.98 & 0.17 & 1.69 & 2.40 & \multirow{3}{*}{1.374} & \multirow{3}{*}{$2 ; 87$} & \multirow{3}{*}{ ns } \\
\hline & TIVA & 1.94 & 0.15 & 1.66 & 2.19 & & & \\
\hline & VIMA & 1.91 & 0.19 & 1.54 & 2.39 & & & \\
\hline
\end{tabular}

Legenda: GBA - opšta balansirana anestezija, TIVA - totalna intravenska anestezija, VIMA - volatilna indukcija i održavanje anestezije, $\mathrm{x}$ - srednja vrednost, $\mathrm{SD}$ - standardna devijacija, min i max - granične vrednosti, $\mathrm{p}$ - statistički značaj

Komparativnu analizu dobijenih vrednosti (izmerenih hemodinamskih parametara) izvršili smo na sledeći način:

- vrednosti u svim trenucima u odnosu na prvi (tj. referentni) momenat (prikazan kao $2,3,4,5,6,7$ do 1$)$

- promene vrednosti parametara iz prethodnog u sledeći (prikazano kao promena $1 \rightarrow 2$, $2 \rightarrow 3,3 \rightarrow 4,4 \rightarrow 5,5 \rightarrow 6,6 \rightarrow 7)$

- promene vrednosti parametara od prethodnog do sledećeg trenutka između grupa:
Rezultati deskriptivne statističke analize SBP-a u grupama su prikazani u tabeli 3 .

U GBA grupi postoji statistički visoko značajna promena srednjih vrednosti SBP u posmatranom periodu $(\mathrm{F}=90,187 ; \mathrm{df}=6 ; \mathrm{p}=0,000)$. Sve izmerene vrednosti značajno se razlikuju od prve, a i sledeće vrednosti značajno se razlikuju: $1 \rightarrow 2$, $2 \rightarrow 3,3 \rightarrow 4,5 \rightarrow 6$ i $6 \rightarrow 7$ ( $4 \rightarrow 5$ se ne razlikuju značajno) (tabela 4$)$.

U TIVA grupi, tokom posmatranog perioda, postoji statistički visoko značajna promena sred- 
Tabela 3: Deskriptivni statistički parametri SBP-a po grupama

\begin{tabular}{|c|c|c|c|c|c|}
\hline Karakteristike & Grupa & $\mathbf{x}$ & SD & $\min$ & $\max$ \\
\hline \multirow[t]{3}{*}{ SBP 1} & GBA & 125.47 & 13.34 & 105.00 & 148.00 \\
\hline & TIVA & 122.73 & 10.89 & 105.00 & 140.00 \\
\hline & VIMA & 130.67 & 10.08 & 108.00 & 145.00 \\
\hline \multirow[t]{3}{*}{ SBP 2} & GBA & 160.87 & 18.99 & 132.00 & 195.00 \\
\hline & TIVA & 106.50 & 10.59 & 85.00 & 128.00 \\
\hline & VIMA & 147.10 & 11.63 & 118.00 & 172.00 \\
\hline \multirow[t]{3}{*}{ SBP 3} & GBA & 107.73 & 9.40 & 90.00 & 125.00 \\
\hline & TIVA & 101.03 & 10.60 & 82.00 & 125.00 \\
\hline & VIMA & 128.10 & 9.44 & 108.00 & 147.00 \\
\hline \multirow[t]{3}{*}{ SBP 4} & GBA & 142.63 & 12.98 & 125.00 & 166.00 \\
\hline & TIVA & 119.20 & 10.74 & 100.00 & 145.00 \\
\hline & VIMA & 138.37 & 9.43 & 122.00 & 155.00 \\
\hline \multirow[t]{3}{*}{ SBP 5} & GBA & 146.57 & 16.13 & 118.00 & 177.00 \\
\hline & TIVA & 116.07 & 9.93 & 103.00 & 140.00 \\
\hline & VIMA & 126.00 & 8.94 & 108.00 & 142.00 \\
\hline \multirow[t]{3}{*}{ SBP 6} & GBA & 137.63 & 11.77 & 118.00 & 166.00 \\
\hline & TIVA & 114.73 & 9.55 & 95.00 & 130.00 \\
\hline & VIMA & 118.40 & 6.62 & 105.00 & 131.00 \\
\hline \multirow[t]{3}{*}{ SBP 7} & GBA & 151.57 & 11.56 & 125.00 & 175.00 \\
\hline & TIVA & 128.97 & 11.70 & 110.00 & 154.00 \\
\hline & VIMA & 137.07 & 10.33 & 120.00 & 162.00 \\
\hline
\end{tabular}

Legenda: GBA - opšta balansirana anestezija, TIVA - totalna intravenska anestezija, VIMA - volatilna indukcija i održavanje anestezije, $x$ - srednja vrednost, SD - standardna devijacija, min i max - granične vrednosti, SBP sistolni krvni pritisak

njih vrednosti $\operatorname{SBP}(\mathrm{F}=73,129 ; \mathrm{df}=6 ; \mathrm{p}=0,000)$. Sve izmerene vrednosti, osim četvrte, značajno se razlikuju od prve, a i sledeće vrednosti se značajno razlikuju: $1 \rightarrow 2,2 \rightarrow 3,3 \rightarrow 4,4 \rightarrow 5(0,053)$ i $6 \rightarrow 7(5 \rightarrow 6$ se ne razlikuju značajno) (tabela 4 ).

U VIMA grupi postoji statistički visoko značajna promena srednjih vrednosti SBP tokom posmatranog perioda $(\mathrm{F}=58,517 ; \mathrm{df}=6 ; \mathrm{p}=0,000)$. Sve izmerene vrednosti, osim treće, značajno se razlikuju od prve, a takođe se i sledeće vrednosti značajno razlikuju: $1 \rightarrow 2,2 \rightarrow 3,3 \rightarrow 4,4 \rightarrow 5,5 \rightarrow 6$ i $6 \rightarrow 7$ (tabela 4 ).

Postoji statistički visoko značajna razlika u promeni srednjih vrednosti SBP između grupa GBA i TIVA $(\mathrm{F}=61,100 ; \mathrm{df}=6 ; \mathrm{p}=0,000) \mathrm{u}$ sledećim merenjima: $1 \rightarrow 2,2 \rightarrow 3,3 \rightarrow 4,4 \rightarrow 5$ i $5 \rightarrow 6$ (nema značajne razlike u promeni za $6 \rightarrow 7$ ) (tabela 5).

Postoji statistički visoko značajna razlika u promeni srednjih vrednosti SBP između grupa GBA i
VIMA $(\mathrm{F}=44,958 ; \mathrm{df}=6 ; \mathrm{p}=0,000) \mathrm{u}$ sledećim merenjima: $1 \rightarrow 2,2 \rightarrow 3,3 \rightarrow 4$ i $4 \rightarrow 5$ (nema značajnih razlika u promenama za $5 \rightarrow 6$ i $6 \rightarrow 7$ ) (tabela 5).

Postoji statistički visoko značajna razlika u promeni srednjih vrednosti SBP između grupa TIVA i VIMA $(F=63,901 ; d f=6 ; p=0,000)$ u sledećim merenjima: $1 \rightarrow 2,2 \rightarrow 3,3 \rightarrow 4,4 \rightarrow 5$ i $5 \rightarrow 6$ (nema značajne razlike u promeni za $6 \rightarrow 7$ ) (tabela 5 ).

Vrednosti SBP u posmatranim grupama grafički su prikazane u dijagramu 1 .

Rezultati deskriptivne statističke analize DBP u grupama prikazani su u tabeli 6 .

U grupi GBA postoji statistički visoko značajna promena DBP srednjih vrednosti u posmatranom periodu $(\mathrm{F}=61,014 ; \mathrm{df}=6 ; \mathrm{p}=0,000)$. Sve izmerene vrednosti značajno se razlikuju od prve, a sledeće vrednosti značajno se razlikuju u sledećim merenjima: $1 \rightarrow 2,2 \rightarrow 3,3 \rightarrow 4$ i $5 \rightarrow 6(4 \rightarrow 5$ i $6 \rightarrow 7$ se ne razlikuju značajno) (tabela 7$)$. 
Dijagram 1: Grafičko poređenje srednjih vrednosti SBP-a između grupa

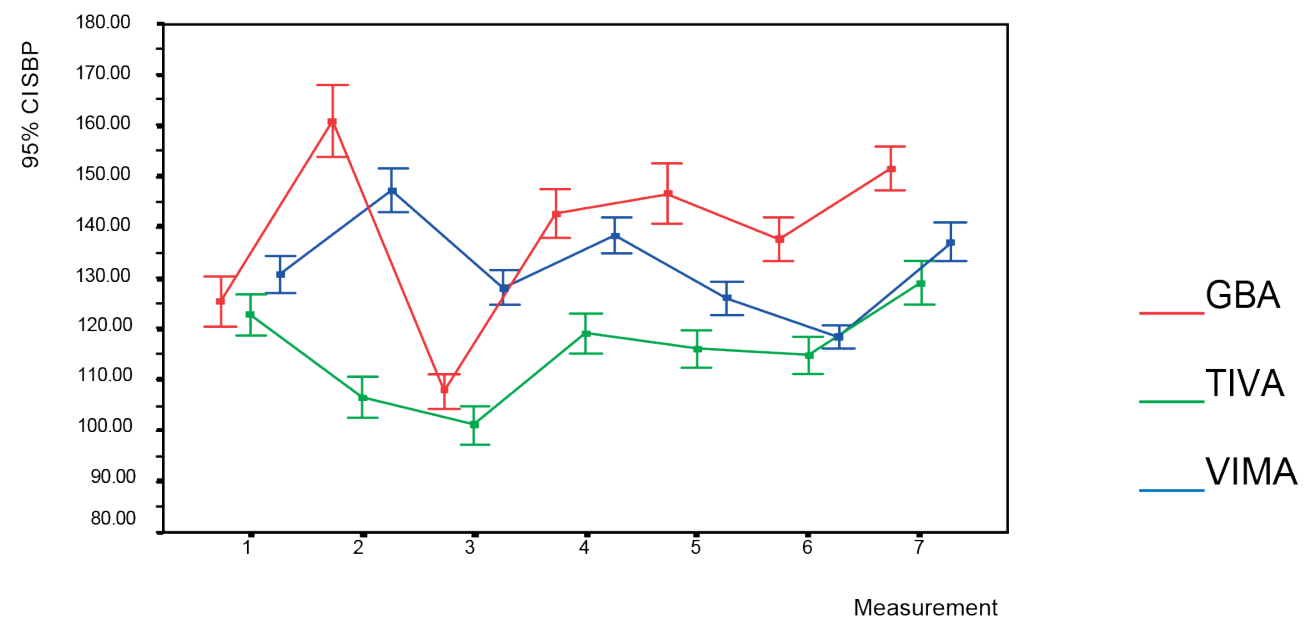

Legenda: GBA - opšta balansirana anestezija, TIVA - totalna intravenska anestezija, VIMA - volatilna indukcija i održavanje anestezija

Tabela 4: Značaj promena srednjih vrednosti SBP-a po grupama

\begin{tabular}{|c|c|c|c|c|}
\hline Grupa & $\mathbf{F}$ & df & p & Upoređivana merenja \\
\hline GBA & 90.187 & 6 & 0.000 & $\begin{array}{l}2,3,4,5,6,7 \text { to } 1 ; \\
1 \rightarrow 2,2 \stackrel{3}{\rightarrow} 3,3 \stackrel{4}{\rightarrow}, 5 \rightarrow 7\end{array}$ \\
\hline TIVA & 73.129 & 6 & 0.000 & $\begin{aligned} & 2,3,5,6,7 \text { to } \\
1 \rightarrow 2,2 \rightarrow 3,3 \rightarrow 4,4 \rightarrow 5 & (0.053), 6 \rightarrow 7\end{aligned}$ \\
\hline VIMA & 58.517 & 6 & 0.000 & $\begin{aligned} 2,4,5,6,7 \text { to } 1 ; & 1 \rightarrow 2,2 \rightarrow 3,3 \rightarrow 4,4 \rightarrow 5,5 \rightarrow 6\end{aligned}$ \\
\hline
\end{tabular}

Legenda: GBA - opšta balansirana anestezija, TIVA - totalna intravenska anestezija, VIMA - volatilna indukcija i održavanje anestezije

Tabela 5: Značajnost razlika promene srednjih vrednosti SBP-a između grupa

\begin{tabular}{|c|c|c|c|c|}
\hline Upoređivane grupe & F & df & p & Upoređivana merenja \\
\hline GBA - TIVA & 61.100 & 6 & 0.000 & $1 \rightarrow 2,2 \rightarrow 3,3 \rightarrow 4,4 \rightarrow 5,5 \rightarrow 6$ \\
\hline GBA- VIMA & 44.958 & 6 & 0.000 & $1 \rightarrow 2,2 \rightarrow 3,3 \rightarrow 4,4 \rightarrow 5$ \\
\hline TIVA-VIMA & 63.901 & 6 & 0.000 & $1 \rightarrow 2,2 \rightarrow 3,3 \rightarrow 4,4 \rightarrow 5,5 \rightarrow 6$ \\
\hline
\end{tabular}

Legenda: GBA - opšta balansirana anestezija, TIVA - totalna intravenska anestezija, VIMA - volatilna indukcija i održavanje anestezije

U TIVA grupi postoji statistički visoko značajna promena DBP srednjih vrednosti u posmatranom periodu $(F=58,198 ; \mathrm{df}=6 ; \mathrm{p}=0,000)$. Sve izmerene vrednosti, osim sedme, značajno se razlikuju od prve, a i sledeće vrednosti se značajno razlikuju: $1 \rightarrow 2,2 \rightarrow 3,3 \rightarrow 4,5 \rightarrow 6$ i $6 \rightarrow 7(4 \rightarrow 5$ se ne razlikuju značajno) (tabela 7 ).

U VIMA grupi postoji statistički visoko značajna promena $\mathrm{DBP}$ srednjih vrednosti u posmatranom periodu $(\mathrm{F}=25,458 ; \mathrm{df}=6 ; \mathrm{p}=0,000)$.
Sve izmerene vrednosti, osim šeste, značajno se razlikuju od prve, ai sledeće vrednosti se značajno razlikuju: $1 \rightarrow 2,2 \rightarrow 3,3 \rightarrow 4,5 \rightarrow 6$ i $6 \rightarrow 7$ ( $4 \rightarrow 5$ se ne razlikuju značajno) (tabela 7 ).

Postoji statistički visoko značajna razlika u promeni srednjih vrednosti DBP između grupa GBA i TIVA $(\mathrm{F}=18,315 ; \mathrm{df}=6 ; \mathrm{p}=0,000) \mathrm{u}$ sledećim merenjima: $1 \rightarrow 2,2 \rightarrow 3,3 \rightarrow 4$ i $6 \rightarrow 7$ (nema značajnih razlika u promenama za $4 \rightarrow 5$ i $5 \rightarrow 6$ ) (tabela 8$)$. 
Tabela 5: Značajnost razlika promene srednjih vrednosti SBP-a između grupa

\begin{tabular}{|c|c|c|c|c|}
\hline Upoređivane grupe & F & df & $\mathbf{p}$ & Upoređivana merenja \\
\hline GBA - TIVA & 61.100 & 6 & 0.000 & $1 \rightarrow 2,2 \rightarrow 3,3 \rightarrow 4,4 \rightarrow 5,5 \rightarrow 6$ \\
\hline GBA- VIMA & 44.958 & 6 & 0.000 & $1 \rightarrow 2,2 \rightarrow 3,3 \rightarrow 4,4 \rightarrow 5$ \\
\hline TIVA-VIMA & 63.901 & 6 & 0.000 & $1 \rightarrow 2,2 \rightarrow 3,3 \rightarrow 4,4 \rightarrow 5,5 \rightarrow 6$ \\
\hline
\end{tabular}

Legenda: GBA - opšta balansirana anestezija, TIVA - totalna intravenska anestezija, VIMA - volatilna indukcija i održavanje anestezije

Tabela 6: Deskriptivni statistički parametri DBP-a po grupama

\begin{tabular}{|c|c|c|c|c|c|}
\hline Karakteristika & Grupa & $\mathbf{x}$ & SD & $\min$ & $\max$ \\
\hline \multirow[t]{3}{*}{ DBP 1} & GBA & 81.07 & 7.27 & 66.00 & 95.00 \\
\hline & TIVA & 80.53 & 9.58 & 65.00 & 95.00 \\
\hline & VIMA & 85.43 & 7.76 & 68.00 & 95.00 \\
\hline \multirow[t]{3}{*}{ DBP 2} & GBA & 96.00 & 9.87 & 80.00 & 120.00 \\
\hline & TIVA & 71.93 & 8.70 & 55.00 & 85.00 \\
\hline & VIMA & 96.26 & 9.27 & 81.00 & 112.00 \\
\hline \multirow[t]{3}{*}{ DBP 3} & GBA & 73.20 & 7.52 & 60.00 & 85.00 \\
\hline & TIVA & 68.30 & 6.76 & 56.00 & 80.00 \\
\hline & VIMA & 89.73 & 8.48 & 77.00 & 105.00 \\
\hline \multirow[t]{3}{*}{ DBP 4} & GBA & 103.17 & 11.44 & 80.00 & 125.00 \\
\hline & TIVA & 90.67 & 11.53 & 74.00 & 112.00 \\
\hline & VIMA & 94.43 & 8.63 & 79.00 & 110.00 \\
\hline \multirow[t]{3}{*}{ DBP 5} & GBA & 100.07 & 11.59 & 75.00 & 122.00 \\
\hline & TIVA & 90.43 & 7.91 & 70.00 & 105.00 \\
\hline & VIMA & 91.90 & 6.94 & 75.00 & 105.00 \\
\hline \multirow[t]{3}{*}{ DBP 6} & GBA & 90.63 & 6.73 & 78.00 & 102.00 \\
\hline & TIVA & 80.17 & 5.09 & 71.00 & 92.00 \\
\hline & VIMA & 83.53 & 5.14 & 72.00 & 95.00 \\
\hline \multirow[t]{3}{*}{ DBP 7} & GBA & 89.90 & 4.49 & 78.00 & 97.00 \\
\hline & TIVA & 84.37 & 4.41 & 70.00 & 92.00 \\
\hline & VIMA & 92.13 & 4.14 & 82.00 & 102.00 \\
\hline
\end{tabular}

Legenda: GBA - opšta balansirana anestezija, TIVA - totalna intravenska anestezija, VIMA - volatilna indukcija i održavanje anestezije, $\mathrm{x}$ - srednja vrednost, SD - standardna devijacija, min i max - granične vrednosti, DBP dijastolni krvni pritisak

Postoji statistički visoko značajna razlika u promeni DBP srednjih vrednosti između grupa GBA i VIMA $(\mathrm{F}=30,261 ; \mathrm{df}=6 ; \mathrm{p}=0,000)$ u sledećim merenjima: $1 \rightarrow 2,2 \rightarrow 3,3 \rightarrow 4$ i $6 \rightarrow 7$ (nema značajnih razlika u promenama za $4 \rightarrow 5$ i $5 \rightarrow 6$ ) (tabela 8 ).

Postoji statistički visoko značajna razlika u promeni DBP srednjih vrednosti između grupa TIVA i VIMA $(\mathrm{F}=41,521 ; \mathrm{df}=6 ; \mathrm{p}=0,000) \mathrm{u}$ sledećim merenjima: $1 \rightarrow 2,2 \rightarrow 3,3 \rightarrow 4$ i $6 \rightarrow 7$ (nema značajnih razlika u promenama za $4 \rightarrow 5$ i $5 \rightarrow 6$ ) (ta- bela 8). Vrednosti DBP u posmatranim grupama grafički su prikazane na dijagramu 2.

Sledeći parametar koji je praćen je HR, koji je u suštini određen automatizmom pejsmejkera srca, a u velikoj meri zavisi od neuralnih i humoralnih uticaja, čiji se intenzitet često menja tokom LC.

$\mathrm{S}$ obzirom na to da hemodinamske varijable $\mathrm{u}$ ovom istraživanju nisu merene invazivno, zaključci bazirani na prikupljenim podacima će upućivati samo na trend promena CO, SV, TPR i CI. Prikaz 
Tabela 7: Deskriptivni statistički parametri DBP-a po grupama

\begin{tabular}{|c|c|c|c|c|}
\hline Grupa & F & df & p & Upoređivana merenja \\
\hline GBA & 61.014 & 6 & 0.000 & $\begin{array}{c}2,3,4,5,6,7 \text { to } 1 ; \\
1 \rightarrow 2,2 \stackrel{2}{\rightarrow} 3,3 \rightarrow 4,5 \rightarrow 6\end{array}$ \\
\hline TIVA & 58.198 & 6 & 0.000 & $\begin{array}{c}2,3,4,5,7(0.050) \text { to } 1 ; \\
1 \rightarrow 2,2 \rightarrow 3,3 \rightarrow 4,5 \rightarrow 6,6 \rightarrow 7\end{array}$ \\
\hline VIMA & 25.458 & 6 & 0.000 & $\begin{array}{c}2,3,4,5,7 \text { to } 1 ; \\
1 \rightarrow 2,2 \rightarrow 3,3 \rightarrow 4,5 \rightarrow 6,6 \rightarrow 7\end{array}$ \\
\hline
\end{tabular}

Legenda: GBA - opšta balansirana anestezija, TIVA - totalna intravenska anestezija, VIMA - volatilna indukcija i održavanje anestezije

Tabela 8: Značajnost razlika promene srednjih vrednosti DBP-a između grupa

\begin{tabular}{|c|c|c|c|c|}
\hline $\begin{array}{c}\text { Upoređivane } \\
\text { grupe }\end{array}$ & F & df & $\mathbf{p}$ & Upoređivana merenja \\
\hline GBA - TIVA & 18.315 & 6 & 0.000 & $1 \rightarrow 2,2 \rightarrow 3,3 \rightarrow 4,6 \rightarrow 7$ \\
\hline GBA - VIMA & 30.621 & 6 & 0.000 & $1 \rightarrow 2,2 \rightarrow 3,3 \rightarrow 4,6 \rightarrow 7$ \\
\hline TIVA- VIMA & 41.521 & 6 & 0.000 & $1 \rightarrow 2,2 \rightarrow 3,3 \rightarrow 4,6 \rightarrow 7$ \\
\hline
\end{tabular}

Legenda: GBA - opšta balansirana anestezija, TIVA - totalna intravenska anestezija, VIMA - volatilna indukcija i održavanje anestezije

Dijagram 2: Grafičko poređenje srednjih vrednosti DBP-a između grupa

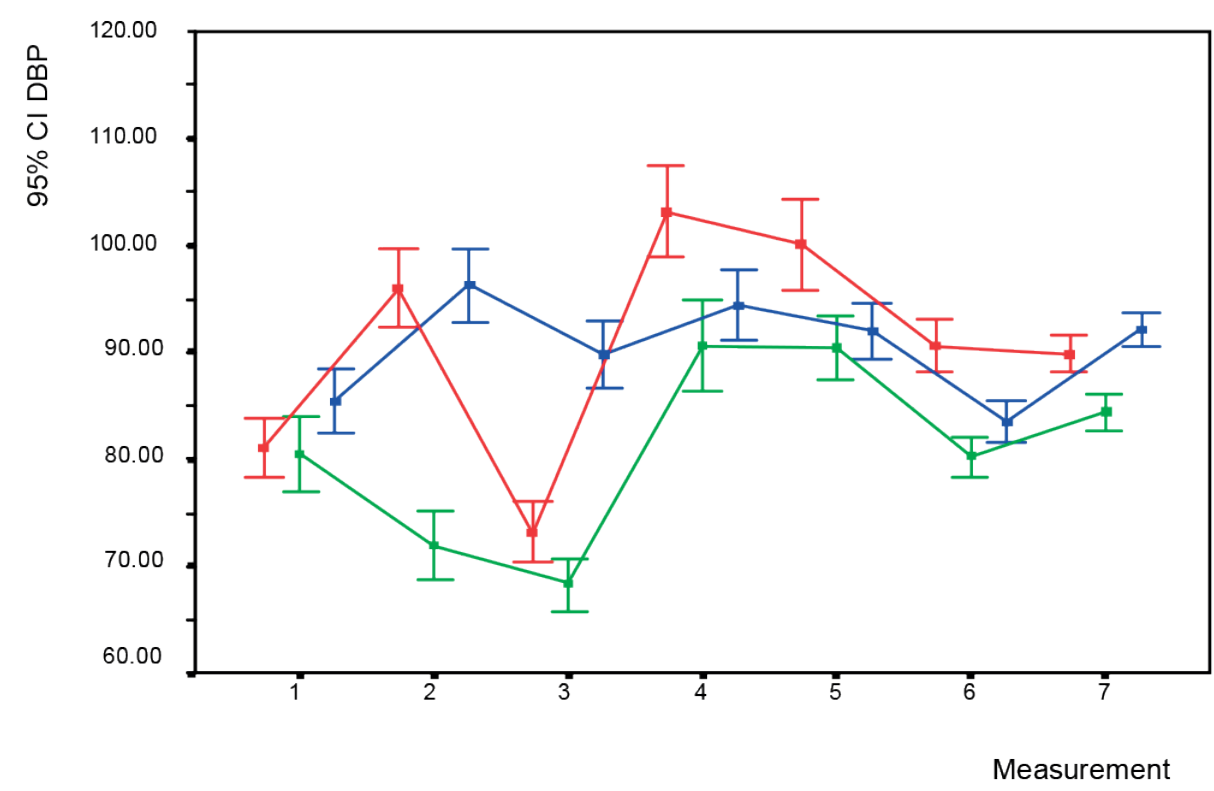

GBA

TIVA

VIMA

Legenda: GBA - opšta balansirana anestezija, TIVA - totalna intravenska anestezija, VIMA - volatilna indukcija i održavanje anestezija

trenda promena CO, SV, TPR, CI kod pacijenata ASA klase I, može biti od pomoći prilikom donošenja odluka o lečenju pacijenata ASA klase II, III i IV, a oni su sve češći u svakodnevnoj laparoskopskoj hirurgiji žučne kese. 
Tabela 9: Deskriptivni statistički parametri HR-a po grupama

\begin{tabular}{|c|c|c|c|c|c|}
\hline Karakteristika & Grupa & $\mathrm{x}$ & $\mathrm{SD}$ & $\min$ & $\max$ \\
\hline \multirow[t]{3}{*}{ HR 1} & GBA & 80.27 & 12.86 & 56.00 & 105.00 \\
\hline & TIVA & 81.00 & 13.30 & 66.00 & 110.00 \\
\hline & VIMA & 89.50 & 8.79 & 75.00 & 105.00 \\
\hline \multirow[t]{3}{*}{ HR 2} & GBA & 109.93 & 15.75 & 75.00 & 143.00 \\
\hline & TIVA & 82.07 & 14.31 & 56.00 & 115.00 \\
\hline & VIMA & 93.43 & 8.00 & 79.00 & 107.00 \\
\hline \multirow[t]{3}{*}{ HR 3} & GBA & 114.90 & 7.74 & 104.00 & 136.00 \\
\hline & TIVA & 89.47 & 14.31 & 68.00 & 122.00 \\
\hline & VIMA & 93.43 & 8.00 & 83.00 & 112.00 \\
\hline \multirow[t]{3}{*}{ HR 4} & GBA & 98.17 & 8.45 & 78.00 & 115.00 \\
\hline & TIVA & 74.07 & 11.07 & 55.00 & 96.00 \\
\hline & VIMA & 85.40 & 7.73 & 71.00 & 97.00 \\
\hline \multirow[t]{3}{*}{ HR 5} & GBA & 104.93 & 7.75 & 92.00 & 118.00 \\
\hline & TIVA & 79.70 & 9.99 & 60.00 & 102.00 \\
\hline & VIMA & 79.97 & 7.50 & 66.00 & 95.00 \\
\hline \multirow[t]{3}{*}{ HR 6} & GBA & 104.63 & 8.46 & 89.00 & 121.00 \\
\hline & TIVA & 84.80 & 9.32 & 72.00 & 105.00 \\
\hline & VIMA & 76.00 & 7.73 & 62.00 & 91.00 \\
\hline \multirow[t]{3}{*}{ HR 7} & GBA & 101.33 & 13.78 & 82.00 & 133.00 \\
\hline & TIVA & 97.63 & 10.27 & 81.00 & 121.00 \\
\hline & VIMA & 87.57 & 4.99 & 76.00 & 95.00 \\
\hline
\end{tabular}

Legenda: GBA - opšta balansirana anestezija, TIVA - totalna intravenska anestezija, VIMA - volatilna indukcija i održavanje anestezije, $\mathrm{x}$ - srednja vrednost, $\mathrm{SD}$ - standardna devijacija, min i max - granične vrednosti, HR srčana frekvenca

Diagram 3: Grafičko poređenje srednjih vrednosti HR-a između grupa

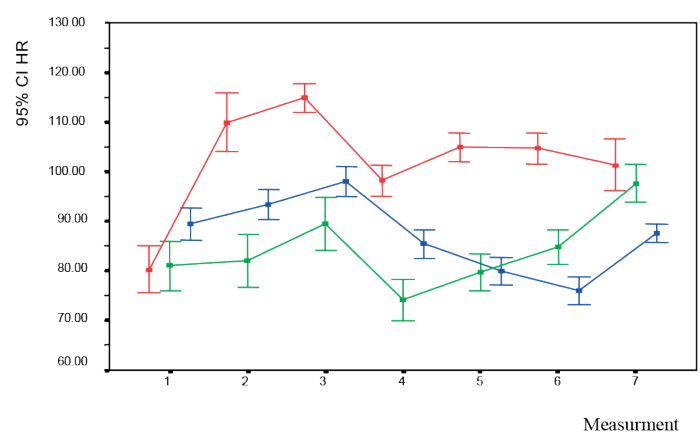


Tabela 10: Deskriptivni statistički parametri HR-a po grupama

\begin{tabular}{|c|c|c|c|c|}
\hline Grupa & F & df & p & Upoređivana merenja \\
\hline GBA & 33.045 & 6 & 0.000 & $\begin{array}{c}2,3,4,5,6,7 \text { to } 1 ; \\
1 \rightarrow 2,3 \rightarrow 4,4 \rightarrow 5\end{array}$ \\
\hline TIVA & 31.186 & 6 & 0.000 & $\begin{array}{c}3,4,7 \text { to } 1 ; \\
2 \rightarrow 3,3 \rightarrow 4,4 \rightarrow 5,5 \rightarrow 6,6 \rightarrow 7\end{array}$ \\
\hline VIMA & 73.110 & 6 & 0.000 & $\begin{array}{c}2,3,4,5,6 \text { to } 1 ; \\
1 \rightarrow 2,2 \rightarrow 3,3 \rightarrow 4,4 \rightarrow 5,5 \rightarrow 6, \\
6 \rightarrow 7\end{array}$ \\
\hline
\end{tabular}

Legenda: GBA - opšta balansirana anestezija, TIVA - totalna intravenska anestezija, VIMA - volatilna indukcija i održavanje anestezije

Tabela 11: Značajnost razlika promene srednjih vrednosti HR-a između grupa

\begin{tabular}{|c|c|c|c|c|}
\hline Upoređivane grupe & F & $\mathbf{d f}$ & $\mathbf{p}$ & Upoređivana merenja \\
\hline GBA-TIVA & 24.076 & 6 & 0.000 & $1 \rightarrow 2,5 \rightarrow 6,6 \rightarrow 7$ \\
\hline GBA-VIMA & 32.948 & 6 & 0.000 & $1 \rightarrow 2,4 \rightarrow 5,6 \rightarrow 7$ \\
\hline TIVA-VIMA & 32.818 & 6 & 0.000 & $2 \rightarrow 3,3 \rightarrow 4^{(0.053)}, 4 \rightarrow 5,5 \rightarrow 6$ \\
\hline
\end{tabular}

Legenda: GBA - opšta balansirana anestezija, TIVA - totalna intravenska anestezija, VIMA - volatilna indukcija i održavanje anestezije

Dijagram 4: Grafičko poređenje CO srednjih vrednosti između grupa

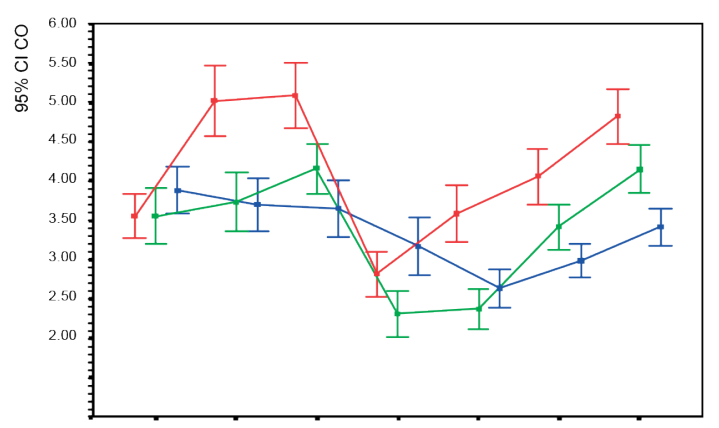
GBA TIVA VIMA

Legenda: GBA - opšta balansirana anestezija, TIVA - totalna intravenska anestezija, VIMA - volatilna indukcija i održavanje anestezija

Dijagram 5: Grafičko poređenje srednjih vrednosti TPR-a između grupa
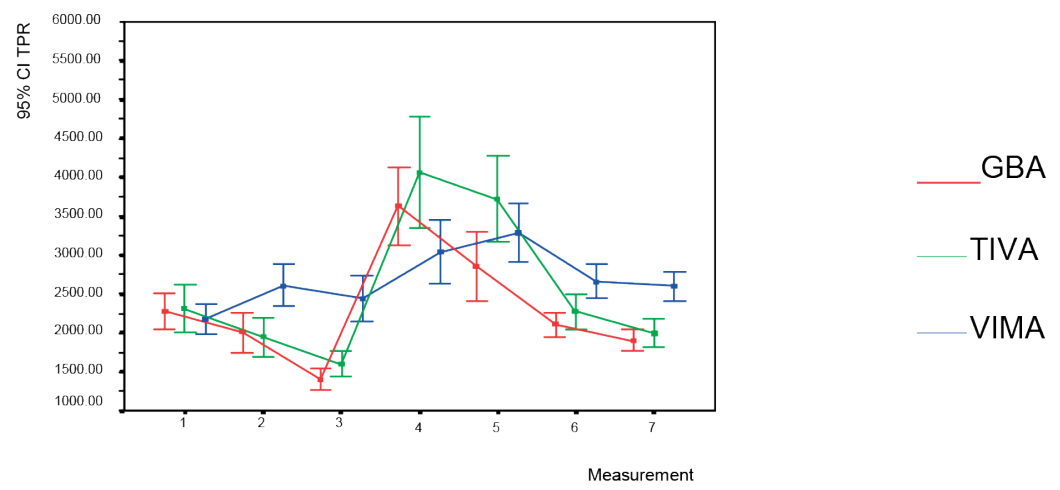

Legenda: GBA - opšta balansirana anestezija, TIVA - totalna intravenska anestezija, VIMA - volatilna indukcija i održavanje anestezija 
Tabela 12: Deskriptivni statistički parametri CO-a po grupama

\begin{tabular}{|c|c|c|c|c|c|}
\hline Karakteristika & Grupa & $\mathbf{x}$ & SD & $\min$ & $\mathbf{m a x}$ \\
\hline \multirow{4}{*}{ CO 1 } & GBA & 3.55 & 0.76 & 2.22 & 5.00 \\
\cline { 2 - 6 } & TIVA & 3.56 & 0.96 & 1.54 & 6.46 \\
\cline { 2 - 6 } & VIMA & 3.87 & 0.80 & 2.60 & 5.79 \\
\hline \multirow{4}{*}{ CO 2 } & GBA & 5.02 & 1.21 & 2.51 & 7.38 \\
\cline { 2 - 6 } & TIVA & 3.73 & 1.00 & 1.88 & 6.09 \\
\cline { 2 - 6 } & VIMA & 3.70 & 0.90 & 2.47 & 5.48 \\
\hline CO 3 & GBA & 5.09 & 1.10 & 2.95 & 7.07 \\
\cline { 2 - 6 } & TIVA & 4.16 & 0.86 & 2.16 & 5.96 \\
\cline { 2 - 6 } & VIMA & 3.65 & 0.97 & 1.89 & 5.86 \\
\hline CO 4 & GBA & 2.81 & 0.76 & 1.54 & 4.70 \\
\cline { 2 - 6 } & TIVA & 2.31 & 0.79 & 1.08 & 3.63 \\
\cline { 2 - 6 } & VIMA & 3.17 & 0.96 & 1.48 & 5.38 \\
\hline \multirow{5}{*}{ CO 5 } & GBA & 3.58 & 0.97 & 1.64 & 5.25 \\
\cline { 2 - 6 } & TIVA & 2.37 & 0.69 & 1.09 & 3.72 \\
\cline { 2 - 6 } & VIMA & 2.63 & 0.66 & 1.25 & 3.71 \\
\hline CO 6 & GBA & 4.06 & 0.96 & 1.04 & 6.16 \\
\cline { 2 - 6 } & TIVA & 3.41 & 0.78 & 1.98 & 5.04 \\
\cline { 2 - 6 } & VIMA & 2.98 & 0.58 & 1.64 & 4.05 \\
\hline CO 7 & GBA & 4.82 & 0.94 & 3.12 & 6.61 \\
\cline { 2 - 6 } & TIVA & 4.15 & 0.83 & 2.29 & 5.58 \\
\cline { 2 - 5 } & VIMA & 3.41 & 0.64 & 2.11 & 4.89 \\
\hline
\end{tabular}

Legenda: GBA - opšta balansirana anestezija, TIVA - totalna intravenska anestezija, VIMA - volatilna indukcija i održavanje anestezije, $\mathrm{x}$ - srednja vrednost, $\mathrm{SD}$ - standardna devijacija, min i max - granične vrednosti, CO minutni volumen srca

Tabela 13: Deskriptivni statistički parametri CO-a po grupama

\begin{tabular}{|c|c|c|c|c|}
\hline Grupa & $\mathbf{F}$ & df & $\mathbf{p}$ & Upoređivana merenja \\
\hline GBA & 34.102 & 6 & 0.000 & $\begin{array}{c}2,3,4,6,7 \text { to } 1 ; \\
1 \rightarrow 2,3 \stackrel{4}{\rightarrow}, 4 \stackrel{4}{\rightarrow}, 5 \rightarrow 6,6 \rightarrow 7\end{array}$ \\
\hline TIVA & 51.000 & 6 & 0.000 & $2 \rightarrow 3,3 \stackrel{3,5,7}{\rightarrow} 4,5 \stackrel{\text { to }}{\rightarrow} 6,6 \rightarrow 7$ \\
\hline VIMA & 24.006 & 6 & 0.000 & $\begin{array}{c}2(0.052), \\
1 \rightarrow 2^{(0.052)}, \begin{array}{c}3(0.051), 4,5,6,7 \\
3 \rightarrow 4, \\
6 \rightarrow 7\end{array} \quad 4 \rightarrow 5, \quad 5 \rightarrow 6, \quad \text { to } 1 ;\end{array}$ \\
\hline
\end{tabular}

Legenda: GBA - opšta balansirana anestezija, TIVA - totalna intravenska anestezija, VIMA - volatilna indukcija i održavanje anestezije

Tabela 14: Značajnost razlika promene srednjih vrednosti CO između grupa

\begin{tabular}{|c|c|c|c|c|}
\hline Upoređivane grupe & $\mathbf{F}$ & $\mathbf{d f}$ & $\mathbf{p}$ & Upoređivana merenja \\
\hline GBA - TIVA & 5.850 & 6 & 0.000 & $1 \rightarrow 2,4 \rightarrow 5,5 \rightarrow 6$ \\
\hline GBA - VIMA & 20.574 & 6 & 0.000 & $1 \rightarrow 2,3 \rightarrow 4,4 \rightarrow 5$ \\
\hline TIVA - VIMA & 16.077 & 6 & 0.000 & $\begin{array}{c}1 \rightarrow 2,2 \rightarrow 3,3 \rightarrow 4,4 \rightarrow 5,5 \rightarrow 6, \\
6 \rightarrow 7(0.054)\end{array}$ \\
\hline
\end{tabular}

Legenda: GBA - opšta balansirana anestezija, TIVA - totalna intravenska anestezija, VIMA - volatilna indukcija i održavanje anestezije 
Dijagram 6: Grafičko poređenje srednjih vrednosti CI-a između grupa

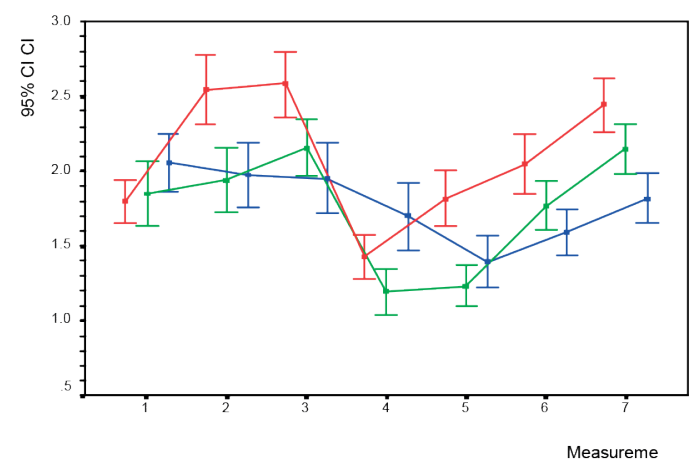
GBA TIVA

VIMA

Legenda: GBA - opšta balansirana anestezija, TIVA - totalna intravenska anestezija, VIMA - volatilna indukcija i održavanje anestezij

Tabela 15: Deskriptivni statistički parametri TPR-a po grupama

\begin{tabular}{|c|c|c|c|c|c|}
\hline Karakteristika & Grupa & $\mathbf{x}$ & SD & $\min$ & $\max$ \\
\hline \multirow{3}{*}{ TPR 1} & GBA & 2274.85 & 621.34 & 1320.69 & 3712.68 \\
\hline & TIVA & 2312.80 & 826.04 & 1006.47 & 5218.79 \\
\hline & VIMA & 2172.27 & 528.69 & 1177.66 & 3206.28 \\
\hline \multirow{3}{*}{ TPR 2} & GBA & 2002.27 & 670.51 & 1315.71 & 4594.20 \\
\hline & TIVA & 1944.15 & 657.41 & 901.20 & 3691.36 \\
\hline & VIMA & 2609.74 & 738.17 & 1462.57 & 4033.75 \\
\hline \multirow{3}{*}{ TPR 3} & GBA & 1405.50 & 395.72 & 915.11 & 2346.98 \\
\hline & TIVA & 1600.78 & 426.41 & 911.23 & 3005.99 \\
\hline & VIMA & 2437.44 & 803.21 & 1317.69 & 4605.73 \\
\hline \multirow{3}{*}{ TPR 4} & GBA & 3629.84 & 1348.99 & 1808.89 & 6917.02 \\
\hline & TIVA & 4062.11 & 1913.35 & 1934.90 & 8746.95 \\
\hline & VIMA & 3042.53 & 1080.18 & 1505.84 & 5909.19 \\
\hline \multirow{3}{*}{ TPR 5} & GBA & 2858.77 & 1187.66 & 1652.61 & 6361.40 \\
\hline & TIVA & 3718.77 & 1493.63 & 1903.06 & 7510.45 \\
\hline & VIMA & 3284.01 & 1010.70 & 2041.16 & 6515.22 \\
\hline \multirow[t]{3}{*}{ TPR 6} & GBA & 2107.66 & 425.11 & 1293.39 & 3145.05 \\
\hline & TIVA & 2267.55 & 582.75 & 1343.90 & 3828.36 \\
\hline & VIMA & 2663.20 & 611.17 & 1743.11 & 4475.13 \\
\hline \multirow[t]{3}{*}{ TPR 7} & GBA & 1901.13 & 394.32 & 1299.41 & 2812.76 \\
\hline & TIVA & 1998.01 & 486.65 & 1403.47 & 3379.98 \\
\hline & VIMA & 2598.44 & 526.28 & 1842.32 & 4253.59 \\
\hline
\end{tabular}

Legenda: GBA - opšta balansirana anestezija, TIVA - totalna intravenska anestezija, VIMA - volatilna indukcija i održavanje anestezije, $\mathrm{x}$ - srednja vrednost, SD - standardna devijacija, min i max - granične vrednosti, TPR periferni vaskularni otpor 
Tabela 16: Deskriptivni statistički parametri TPR-a po grupama

\begin{tabular}{|c|c|c|c|c|}
\hline Grupa & F & df & p & Upoređivana merenja \\
\hline GBA & 31.750 & 6 & 0.000 & $\begin{array}{c}2,3,4,5,7 \text { to } 1 ; \\
1 \rightarrow 2,2 \rightarrow 3,3 \rightarrow 4,4 \rightarrow 5,5 \rightarrow 6,6 \rightarrow 7\end{array}$ \\
\hline TIVA & 38.596 & 6 & 0.000 & $\begin{array}{c}2,3,4,5,7 \text { to } 1 ; \\
1 \rightarrow 2,2 \stackrel{2}{\rightarrow} 3,3 \rightarrow 4,5 \rightarrow 6,6 \rightarrow 7\end{array}$ \\
\hline VIMA & 15.400 & 6 & 0.000 & $\begin{array}{c}2,3,4,5,5,7 \text { to } 1 ; \\
1 \rightarrow 2,2 \rightarrow 3,3 \rightarrow 4,5 \rightarrow 6\end{array}$ \\
\hline
\end{tabular}

Legenda: GBA - opšta balansirana anestezija, TIVA - totalna intravenska anestezija, VIMA - volatilna indukcija i održavanje anestezije

Tabela 17: Značajnost razlika promene srednjih vrednosti TPR između grupa

\begin{tabular}{|c|c|c|c|c|}
\hline Upoređivane grupe & F & df & $\mathbf{p}$ & Upoređivana merenja \\
\hline GBA - TIVA & 2.430 & 6 & 0.026 & $2 \rightarrow 3(0.051), 5 \rightarrow 6$ \\
\hline GBA - VIMA & 11.608 & 6 & 0.000 & $1 \rightarrow 2,2 \rightarrow 3,3 \rightarrow 4,4 \rightarrow 5$ \\
\hline TIVA - VIMA & 14.508 & 6 & 0.000 & $1 \rightarrow 2,2 \rightarrow 3,3 \rightarrow 4,5 \rightarrow 6$ \\
\hline
\end{tabular}

Legenda: GBA - opšta balansirana anestezija, TIVA - totalna intravenska anestezija, VIMA - volatilna indukcija i održavanje anestezije

Tabela 18: Deskriptivni statistički parametri CI-a po grupama

\begin{tabular}{|c|c|c|c|c|c|}
\hline Karakteristika & Grupa & $\mathbf{x}$ & SD & $\min$ & $\mathbf{m a x}$ \\
\hline \multirow{4}{*}{ CI 1 } & GBA & 1.80 & 0.39 & 1.27 & 2.74 \\
\cline { 2 - 6 } & TIVA & 1.85 & 0.57 & 0.81 & 3.88 \\
\cline { 2 - 6 } & VIMA & 2.06 & 0.50 & 1.26 & 3.11 \\
\hline \multirow{4}{*}{ CI 2 } & GBA & 2.54 & 0.62 & 1.24 & 3.93 \\
\cline { 2 - 6 } & TIVA & 1.94 & 0.58 & 0.98 & 3.66 \\
\cline { 2 - 6 } & VIMA & 1.97 & 0.58 & 1.13 & 3.26 \\
\hline \multirow{4}{*}{ CI 3 } & GBA & 2.58 & 0.59 & 1.43 & 4.06 \\
\cline { 2 - 6 } & TIVA & 2.16 & 0.51 & 1.13 & 3.59 \\
\cline { 2 - 6 } & VIMA & 1.95 & 0.62 & 0.89 & 3.23 \\
\hline \multirow{4}{*}{ CI 4 } & GBA & 1.43 & 0.40 & 0.80 & 2.38 \\
\cline { 2 - 6 } & TIVA & 1.19 & 0.41 & 0.61 & 1.86 \\
\cline { 2 - 6 } & VIMA & 1.70 & 0.61 & 0.75 & 3.23 \\
\hline \multirow{4}{*}{ CI 5 } & GBA & 1.82 & 0.50 & 0.89 & 2.64 \\
\cline { 2 - 6 } & TIVA & 1.23 & 0.37 & 0.58 & 1.92 \\
\cline { 2 - 6 } & VIMA & 1.39 & 0.47 & 0.14 & 2.41 \\
\hline \multirow{3}{*}{ CI 6 } & GBA & 2.05 & 0.54 & 0.02 & 3.12 \\
\cline { 2 - 6 } & TIVA & 1.77 & 0.43 & 1.12 & 2.65 \\
\cline { 2 - 6 } & VIMA & 1.59 & 0.42 & 0.86 & 2.52 \\
\hline \hline \multirow{3}{*}{ CI 7 } & GBA & 2.44 & 0.48 & 1.52 & 3.34 \\
\cline { 2 - 6 } & TIVA & 2.15 & 0.44 & 1.14 & 3.05 \\
\cline { 2 - 6 } & VIMA & 1.82 & 0.45 & 0.89 & 2.92 \\
\hline
\end{tabular}

Legenda: GBA - opšta balansirana anestezija, TIVA - totalna intravenska anestezija, VIMA - volatilna indukcija i održavanje anestezije, $\mathrm{x}$ - srednja vrednost, $\mathrm{SD}$ - standardna devijacija, min i max - granične vrednosti, CI - indeks minutnog volumena srca 
Tabela 19: Deskriptivni statistički parametri CI-a po grupama

\begin{tabular}{|c|c|c|c|c|}
\hline Grupa & F & $\mathbf{d f}$ & $\mathbf{p}$ & Upoređivana merenja \\
\hline GBA & 33.376 & 6 & 0.000 & $\begin{array}{c}2,3,4,6,7 \text { to } 1 ; \\
1 \rightarrow 2,3 \rightarrow 4,4 \underset{\rightarrow}{\rightarrow} 5,5 \rightarrow 6,6 \rightarrow 7\end{array}$ \\
\hline TIVA & 48.448 & 6 & 0.000 & $2 \rightarrow 3,3 \stackrel{3,4,5,5 \rightarrow \text { to } 1 ;}{\rightarrow}, 6 \rightarrow 7$ \\
\hline VIMA & 23.000 & 6 & 0.000 & $\begin{array}{c}4,5,5,7,7 \text { to } 1 ; \\
3 \rightarrow 4,4 \rightarrow 5,5 \rightarrow 6,6 \rightarrow 7\end{array}$ \\
\hline
\end{tabular}

Legenda: GBA - opšta balansirana anestezija, TIVA - totalna intravenska anestezija, VIMA - volatilna indukcija i održavanje anestezije

Tabela 20: Značajnost razlika promene srednjih vrednosti CI između grupa

\begin{tabular}{|c|c|c|c|c|}
\hline Upoređivane grupe & $\mathbf{F}$ & $\mathbf{d f}$ & $\mathbf{p}$ & Upoređivana merenja \\
\hline GBA - TIVA & 5.637 & 6 & 0.000 & $1 \rightarrow 2,4 \rightarrow 5,5 \rightarrow 6$ \\
\hline OBA - VIMA & 19.363 & 6 & 0.000 & $1 \rightarrow 2,3 \rightarrow 4,4 \rightarrow 5$ \\
\hline TIVA - VIMA & 14.556 & 6 & 0.000 & $1 \rightarrow 2,2 \rightarrow 3,3 \rightarrow 4,4 \rightarrow 5,5 \rightarrow 6$ \\
\hline
\end{tabular}

Legenda: GBA - opšta balansirana anestezija, TIVA - totalna intravenska anestezija, VIMA - volatilna indukcija i održavanje anestezije

\section{Diskusija}

Endotrahealna intubacija, odmah nakon uvoda $u$ anesteziju, jedan je od najkritičnijih momenata $\mathrm{u}$ toku anesteziološke procedure. $\mathrm{U}$ trenutku intubacije, analgezija još nije maksimalna. U prostoru u kojem se odvijaju manipulacije (tj. usta, ždrelo, larinks i traheje) inervacija je veoma izražena ${ }^{4}$. Pored bola, intubacioni stimulusi izazivaju mnoge reflekse. Aktivnost simpatičkog sistema se povećava, što za posledicu ima promenu u hemodinamici. Hipnotici / analgetici / relaksanti obustavljaju ili bar umanjuju većinu refleksnih i bolnih odgovora, ali simpatički odgovor nikada nije potpuno ukinut ${ }^{5,6}$. Ovaj odgovor se najlakše uočava kroz izmene krvnog pritiska i drugih hemodinamskih parametara. Mladi i zdravi pacijenti dobro tolerišu kolebanja krvnog pritiska potenciranih endotrahealnom intubacijom. Problemi se javljaju kod starijih pacijenata, kao i kod pacijenata sa komorbiditetima $^{7,8}$.

U ovoj studiji su sve tri primenjene tehnike anestezije dovele do promena krvnog pritiska. Najveće promene izmerenih pritisaka (SBP i DBP) dogodile su se u grupi GBA, što se slaže sa rezultatima drugih studija ${ }^{9}$. Važno je napomenuti da je u GBA grupi prilikom uvoda u anesteziju korišćen talamonal, lek koji predstavlja kombinaciju fentanil-citrata i droperidola (dehidrobenzperidol DHBP) iz grupe trankilizera butirofenona, a koji je po završetku ove studije zabranjen od strane Komisije FDA (U.S. Food and Drug Administration), prvenstveno zbog njegovih neželjenih dejstva na srčani ritam. Potvrđeno je da DHBP dovodi do produženja QT intervala i da može da dovede do fatalnih srčanih aritmija ${ }^{10}$. Promene pritisaka u grupama TIVA i VIMA takođe su bile statistički značajne, ali su bile izražene manjim srednjim vrednostima u odnosu na $t_{1}$. SBP u GBA grupi je pokazao najveći porast izazvan indukcijom anestezije i endotrahealne intubacije. Vidi se i porast DBP-a, ali taj porast nakon intubacije je bio manji od rasta SBP-a. Postoje dva moguća objašnjenja za to, ili je anesteziolog neadekvatno izvršio indukciju GBA tehnikom ili je sama GBA tehnika (kao što je izvedeno u ovoj studiji) nedovoljno efektivna u suzbijanju hemodinamskog odgovora na endotrahealnu intubaciju. Treba uzeti u obzir i dejstvo talamonala, korišćenog u GBA grupi, na srčanu funkciju. Sasvim je moguće da bi danas, kombinacijom nekih drugih anestezioloških lekova pri uvodu, uključujući propofol i njegovu sporu aplikaciju, ovaj efekat na sistolni i dijastolni pritisak bio manje izražen. 
U VIMA grupi vrednosti krvnog pritiska su se takođe povećale nakon endotrahealne intubacije, ali statistički značajno manje nego u GBA grupi. Rezultati ove studije jasno pokazuju da je inhalaciona indukcija izvedena u VIMA grupi bila stabilnija od indukcije u GBA grupi. To je u skladu sa dokazanom činjenicom da sevofluran smanjuje simpatički odgovor ${ }^{11}$.

Događaji u grupi TIVA su bili sasvim suprotni onima iz prethodne dve grupe. Indukcija anestezije pomoću propofola i remifentanila je izazvala pad krvnog pritiska, više SBP nego DBP, tako da je pulsni pritisak postao manji. Pad krvnog pritiska nakon indukcije, procenjen na osnovu srednjih vrednosti i relativne alteracije, nije bio klinički značajan u grupi TIVA. Prema našim rezultatima, indukcija anestezije bila je stabilnija u TIVA grupi nego u druge dve grupe.

Period nakon indukcije anestezije i endotrahealne intubacije je bez snažnijih stimulusa za pacijenta. Ovaj period se koristi za pripremu operativnog polja i instrumenata potrebnih za izvođenje operacije. Traje 5-10 minuta. Tokom ovog perioda, istovremeno sa pripremom operativnog polja, pacijent je u anti-Trendelenburg položaju za $20^{\circ}$. Podizanje glave pojačava protok krvi pod uticajem gravitacije. Takvi efekti superponiraju sa depresivnim dejstvom anestetika ${ }^{1}$.

Ako anestezija postane dublja tokom ovog perioda, promene krvnog pritiska postaju veće. Posledično, krvni pritisak pada. Rezultati ove studije jasno pokazuju ovu posledicu u svim posmatranim grupama. Najveća promena, visoko statistički značajna, dogodila se u grupi GBA. Nakon indukcije anestezije upotrebom tiopenton natrijuma, talamonal i fentanil su korišćeni za produbljivanje iste. Treba uzeti u obzir opasnost od depresivnih uticaja ovih lekova na krvni pritisak i srčanu funkciju, u periodu umanjene reakcije organizma na stimulus $^{12}$. Tokom ovog perioda, bilo je veoma teško postići adekvatnu dubinu anestezije pomoću lekova koji su se koristili za GBA, ordiniranih u bolus dozama, a da se održi kardiovaskularna stabilnost.

Daleko manje oscilacije krvnog pritiska uočene su u grupama TIVA i VIMA. U obe grupe krvni pritisak je pao $\mathrm{u} \mathrm{t}_{3} \mathrm{u}$ poređenju sa $\mathrm{t}_{2}$. Pad u grupi TIVA bio je manji i sporiji nego u druge dve grupe. Ovo je uzrokovano mogućnošću da se veoma precizno obezbedi adekvatna dubina aneste- zije intravenskom infuzijom korišćenih hipnotika i analgetika. Inhalacioni anestetik koji se koristi u VIMA tehnici praćen je njegovom end-ekspiracionom koncentracijom, tako da je kontrola dubine anestezije $\mathrm{u}$ ovoj grupi bila jednostavnija nego $\mathrm{u}$ GBA grupi ${ }^{12}$. Postoji statistički visoko značajna razlika između tehnika o kojima je reč u vezi sa $t_{3}$ krvnim pritiscima, a takođe $u$ vezi sa $t_{2} \rightarrow t_{3}$ promenama krvnog pritiska. Odnosi između ovih promena najlakše se razumeju iz grafičkog prikaza kretanja krvnog pritiska. Silazni nagib krivulje od $t_{2}$ do $t_{3}$ u GBA grupi daje jasan prikaz veličine te izmene i njene veze s druge dve grupe. Taj nagib je strmiji nego u grupi VIMA, a još strmiji u grupi TIVA. Oscilacije krvnog pritiska više od $20 \mathrm{mmHg}$ su ređe u TIVA grupi nego u VIMA grupi (u kojoj su ređe u odnosu na grupu GBA).

Momenat $t_{4}$ je definisan kao period od 5 minuta nakon početka stvaranja pneumoperitoneuma. Istezanje peritoneuma je snažan hirurški stimulus. Produbljivanje anestezije ne sme da kasni (u odnosu na ovaj stimulus), jer bi u suprotnom trebalo primeniti veće količine lekova kako bi se postigao njihov adekvatan efekat ${ }^{2}$. $U$ ovoj studiji, uprkos produbljivanju anestezije, svi mereni pritisci su porasli u svim grupama. Ovaj porast je bio najveći u grupi GBA. Posebno je zanimljiv najviši porast DBP pod uticajem pneumoperitoneuma. DBP se neproporcionalno povećao u odnosu na sve ostale izmerene pritiske. Još značajnija je činjenica da je ovaj porast bio rezistentan na dodatno produbljivanje anestezije i da je često u svim grupama bila potrebna upotreba vazodilatora kako bi se normalizovao DBP. Promene krvnog pritiska u $\mathrm{t}_{4}$ se dobro podnosi kod ASA klase I (i verovatno od strane ASA klase II) pacijenata. Naši rezultati ukazuju da je tehnikama TIVA i VIMA lakše preveniran veliki porast krvnog pritiska nego GBA tehnikom. Najočigledniji razlog za ovaj zaključak su specifične farmakokinetičke i farmakodinamičke karakteristike lekova koji se koriste u ovim tehnikama anestezije $\mathrm{e}^{5,6}$.

U našem istraživanju nije bilo značajnih oscilacija vrednosti krvnog pritiska tokom hirurškog rada na žučnoj kesi $\left(t_{5}\right)$. Glavni razlog za ovo zapažanje je da je bilo dovoljno vremena da se uspostavi adekvatna dubina anestezije i da se na taj način stabilizuju ovi hemodinamski parametri. Izmerene vrednosti krvnog pritiska bile su niže $u t_{5}$ nego $\mathrm{ut}_{4}$ u svim grupama. 
Ove vrednosti su se dodatno smanjile $\mathrm{u} \mathrm{t}_{6}$, što je bilo u skladu sa činjenicom da je prestao uticaj velikih hirurških stimulusa i pneumoperitoneuma. Anestezija $u$ periodu $\mathrm{t}_{6}$ mora biti dovoljno duboka kako bi sprečila bolne senzacije koje su uzrokovane provlačenjem žučne kese kroz umbilikalnu inciziju. S druge strane, ovo je period kada se približavamo buđenju pacijenta. Velika promena u periodu $t_{5} \rightarrow t_{6}$ uticala je na DBP, koji se smanjio više nego drugi pritisci, kao što je i njegov prethodni porast bio veći od ostalih. Prema našim rezultatima, ova promena je bila najmanje u grupi TIVA.

U ovoj studiji došlo je do dodatnog povećanja izmerenih pritisaka $\mathrm{u} \mathrm{t}_{7}$, odmah nakon buđenja i ekstubacije pacijenta. To su uobičajene pojave na kraju opšte anestezije. U našoj studiji jedina statistički značajna promena $t_{6} \rightarrow t_{7}$ uočena $u$ promeni DBP. Najveći relativni porast ovih vrednosti dogodio se u VIMA grupi u odnosu na druge dve grupe. Najveći apsolutni porast ovih vrednosti bio je u grupi GBA.

Analiza krivulja vrednosti krvnog pritiska dobijenog u našem istraživanju vodi do zaključka da su promene ovih pritisaka tokom tri izvedene anestetičke tehnike bile manje izražene u grupama TIVA i VIMA nego u grupi GBA. U određenim perioperativnim periodima ove promene su imale suprotan smer u TIVA nego u VIMA grupi, npr. na početku procedure, kada su pritisci smanjeni u grupi TIVA i povećani u grupama VIMA i GBA. Iako je većina uporedivih rezultata u grupama TIVA i VIMA bila statistički različita, klinički značaj promena bio je očigledno manji u ove dve grupe u odnosu na GBA grupu. Zato naši rezultati sugerišu da su anestetičke tehnike TIVA i VIMA stabilnije od GBA tehnike ${ }^{13,14}$.

Grafički prikaz vrednosti HR-a dobijenih u našem istraživanju jasno pokazuje značajne promene u svim grupama, iako različitih intenziteta. Prema našim rezultatima, HR se najmanje povećao sa TIVA tehnikom, zahvaljujući sinergizmu vagalnih toničkih efekata propofola i remifentanila. Zbog lake kontrole ove tehnike anestezije, promene HR (koje se odnose na bazalni nivo) bile su male. Samo su $t_{3}, t_{4} i t_{7}$ bili statistički značajno različiti od $t_{1}$. Ova tehnika je obezbedila veću stabilnost HR tokom cele procedure. Opseg HR oscilacija bio je manji u grupi TIVA nego u grupama GBA i VIMA, tokom većeg dela anestetičke procedure. Maksimalna vrednost HR dostignuta u
GBA grupi bila je $143 \mathrm{bpm} \mathrm{u} \mathrm{t}_{2}$, u VIMA grupi 112 bpm $\mathrm{ut}_{3}$, i u TIVA grupi $122 \mathrm{bpm} \mathrm{u} \mathrm{t}$. Vrednosti HR u grupama TIVA i VIMA došle su do istog nivoa tokom hirurškog rada na žučnoj kesici, a od tog perioda do kraja procedure su bili u obrnutom odnosu. Vrednosti HR u grupi GBA ostale su na povišenom nivou (koje se odnose na bazalni nivo) tokom cele procedure, čak i nakon prestanka uticaja položaja i pneumoperitoneuma. Čak i nakon stabilizacije krvnog pritiska, vrednosti HR u grupi GBA su ostale povišene.

Vrednosti CO značajno su porasle tokom indukcije anestezije i endotrahealne intubacije $u$ GBA grupi. U grupama TIVA i VIMA ove promene su bile znatno manje, iako je postojala statistički značajna razlika u VIMA grupi. Smanjenje simpatičke reakcije i njenih efekata (npr. porast $\mathrm{HR}$ ) može objasniti manje promene $\mathrm{CO}$ u grupama TIVA i VIMA nego u GBA grupi. Kao što se i očekivalo, najveći pad vrednosti CO u svim grupama dogodio se kada su dva glavna uticaja na pacijenta podvrgnutog takvoj operaciji delovala istovremeno: anti-Trendelendburg položaj i pneumoperitoneum ${ }^{1}$. Nakon prestanka ovih uticaja, CO se postepeno normalizovao. Uprkos depresivnim efektima anestetika na kontraktilnost miokarda, mogućnosti precizne kontrole i prilagođavanja dubine anestezije u grupi TIVA omogućile su nam da ublažimo njihov uticaj na CO više nego u VIMA, pa čak i više nego u GBA grupi.

Promene CI su bile slične promenama prethodnih hemodinamskih parametara. Najveće smanjenje ove značajne hemodinamske varijable dogodilo se pod istovremenim uticajem položaja tela i pneumoperitoneuma. Ovaj pad je bio najmanji u grupi TIVA i najveći u grupi GBA. Nasuprot prethodnim parametrima, TPR se povećava uglavnom pod istovremenima uticajem položaja tela i pneumoperitoneuma. Mladi i zdravi pacijenti, ASA klase I, putem svog autonomnog nervnog sistema (prvenstveno svojim simpatičkim angažovanjem), kompenzuju većinu negativnih uticaja operacije i anestezije na protok krvi u organizmu. Veliko povećanje simpatičke aktivnosti, usled peritonealnog rastezanja i insuflacije gasa, maksimalno utiče na TPR. Prema našim rezultatima, nijedna od anestetičkih tehnika izvedenih u našoj studiji nije ublažila ovaj odgovor. U početku anestezije, dok je pacijent pod uticajem anestetika, određenog režima ventilacije i položaja, TPR promene u GBA grupi bile 
su suprotne od onih u grupama TIVA i VIMA, jer su poslednje dve tehnike bile efikasnije u supresiji simpatičkog odgovora. Međutim, uz dodatni uticaj pneumoperitoneuma, TPR je porastao u svim grupama. TPR se smanjio nakon prestanka efekata položaja tela i peritoneuma, i vrednost TPR se vratila na skoro normalan nivo do kraja procedure.

\section{Zaključak:}

Za laparoskopske operacije žučne kese mogu da se koriste različite tehnike anestezije. Međutim, nema svaka od njih isti nivo kvaliteta i sveukupne bezbednosti pacijenata. Sa hemodinamske tačke gledišta, rezultati naše studije idu u korist anestezioloških tehnika TIVA i VIMA. Ovim tehnikama je omogućena sigurna i jednostavna kontrola dubine anestezije i njeno efikasno prilagođavanje intenzitetu hirurških stimulusa u svakom momentu LCe. Prema našim rezultatima, smatramo da tehnike anestezije TIVA i VIMA imaju prednosti i predstavljaju najbolji izbor za LC. Svakako, najbolje bi bilo kada bi se u skorije vreme ponovila slična klinička studija, uz primenu aktuelnih lekova i savremenih saznanja iz anesteziologije.

\section{Literatura}

1. Perrin M, Fletcher A. Laparoscopic abdominal surgery. Contin Educ Anaesthesia, Crit Care Pain. 2004; 4(4):107110.

2. Hayden P, Cowman S. Anaesthesia for laparoscopic surgery. Contin Educ Anaesthesia, Crit Care Pain. 2011; 11(5):177-180.

3. Hömme R. Anesthesia for laparoscopic interventions. Anaesthesist. 2011; 60(2):175-87.
4. Caldas Navarro JA, Lopes Toledo Filho J, Andreo JC, Souza Silva GH, Banhara MR. Contribution to the anatomic study of the innervation of the posterior and lateral crico-arytenoid muscles. Rev Bras Otorrinolaringol. 2003;69(6).

5. Marik P. Propofol: Therapeutic Indications and Side-Effects. Curr Pharm Des. 2004; 10(29):3639-49.

6. Capey S. Sevoflurane. In: xPharm: The Comprehensive Pharmacology Reference. Elsevier, England, 2008.

7. Brown EN, Purdon PL. The aging brain and anesthesia. Current Opinion in Anaesthesiology. 2013; 26(4):414-9.

8. Bettelli G. Preoperative evaluation in geriatric surgery: Comorbidity, functional status and pharmacological history. Minerva Anestesiologica. 2011; 77(6):637-46.

9. Yao XH, Zhou P, Xiao ZK, Wang B, Chen CY, Qing $\mathrm{ZH}$, et al. Comparison of target controlled propofol infusion and sevoflurane inhalational anesthesia in laparoscopic cholecystectomy. Nan Fang Yi Ke Da Xue Xue Bao. 2007; 27(8):1280-1.

10. Habib AS, Gan TJ. Food and drug administration black box warning on the perioperative use of droperidol: a review of the cases. Anesth Analg 2003; 96:1377-9.

11. Conti A, Iacopino DG, Fodale V, Micalizzi S, Penna O, Santamaria LB. Cerebral haemodynamic changes during propofol-remifentanil or sevoflurane anaesthesia: Transcranial Doppler study under bispectral index monitoring. $\mathrm{Br} \mathrm{J}$ Anaesth. 2006; 97(3):333-9.

12. Kuip EJM, Zandvliet ML, Koolen SLW, Mathijssen RHJ, van der Rijt CCD. A review of factors explaining variability in fentanyl pharmacokinetics; focus on implications for cancer patients. British Journal of Clinical Pharmacology. 2017; 83(2):294-313.

13. Deng X, Zhu T. Clinical comparison of propofol-remifentanil TCI with sevoflurane induction/maintenance anesthesia in laparoscopic cholecystectomy. Pakistan J Med Sci. 2014; 30(5):1017-1021.

14. Chen L, Yu L, Fan Y, Manyande A. A comparison between total intravenous anaesthesia using propofol plus remifentanil and volatile induction/maintenance of anaesthesia using sevoflurane in children undergoing flexible fibreoptic bronchoscopy. Anaesth Intensive Care. 2013; 41(6):742-9. 